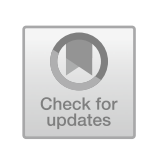

\title{
Our Common Breath: 'Conspiration' from the Stoics to the Church Fathers
}

\author{
Phillip Sidney Horky
}

This essay tracks the metaphorical expansion of the concept of cosmic breathing by locating it in ancient Greco-Roman discourses on cosmology and religion. ${ }^{1}$ Its chronological scope runs from the mid-third century BCE, with the philosophy of the great Stoic Chrysippus, and advances as far as the third century CE, with the Church Father Clement of Alexandria. Over these six centuries, which witnessed extensive transformations of the philosophical and religious worlds of the Mediterranean and Near East, we see an expansion of the concept of breathing through the introduction of a notion of 'conspiration' (the Ancient Greek abstract noun is

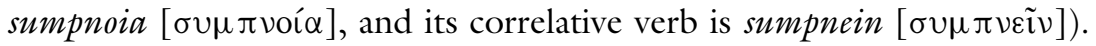
'Conspiration' is my own Anglicization of a concept that refers to the reciprocal breathing that obtains between animate entities, and functions to explain how it is that divine and mortal come together in the cosmos. The concept of 'conspiration' (sumpnoia) is sometimes thought to arise for the first time in the fifth to fourth centuries $\mathrm{BCE}$, being ascribed to

P. S. Horky $(\bowtie)$

Department of Classics and Ancient History, University of Durham, Durham, UK

(C) The Author(s) 2021

D. Fuller et al. (eds.), The Life of Breath in Literature, Culture and Medicine, Palgrave Studies in Literature, Science and Medicine, https://doi.org/10.1007/978-3-030-74443-4_3 
the early Pythagorean Ecphantus of Syracuse and the legendary physician Hippocrates of Chios. I will present an alternative account in which this concept of 'conspiration' actually arises in the third century BCE, in the writings of the Stoics, and in particular Chrysippus of Soli (279$206 \mathrm{BCE}$ ). In order to do so, I will examine a range of evidence from Greek and Latin didactic, philosophical, and theological texts that helps both to contextualize the concept of 'conspiration' in time and place and understand its peculiar aspects.

The Latin version of this notion, conspiratio, which is formed of the verb 'to breathe' (spirare) with the prefix 'with/together' (con-), is first attested in the middle of the first century BCE, in the writings of Cicero, and it had two standard meanings among the Romans. The first meaning is well-known, that is, the notion of 'conspiracy', or an agreement between individuals for the purposes of hostile or illegal activity; ${ }^{2}$ this is a notion that I will not discuss here, since, while it does represent a true cognate in Latin, it would appear to be a derivation that does not represent the original meaning of the term conspiratio; moreover, at least for our purposes, it is notable that this meaning does not get translated back into Greek $\sigma v \mu \pi v o i ́ \alpha$.

The second standard meaning of conspiratio, which appears to be the older and more original one, is also more valuable to our collaborations in this volume: it refers to a kind of agreement in voice-a reciprocal breathing, a concord, a harmony of sorts. ${ }^{3}$ This sort of conspiratio or $\sigma \cup \mu \pi v o i ́ \alpha$ as 'concord' is used in domestic environments to refer to the agreement that, for example, might obtain between a husband and wife: this appears to be a non-marked usage among philosophical schools from the first century BCE onward. ${ }^{4}$ It also appears in the context of civic communities uniting under terms of agreement, such as a league or treaty. ${ }^{5}$ Interestingly, however, 'conspiration' as 'reciprocal breathing' is also used metaphorically to describe how the many parts of the harmonious universe-especially the stars and the planets-relate to the cosmic universe as a whole. Two roughly contemporaneous examples-one in Latin, and one in Greek-demonstrate this sort of expression:

Tl: This fabric which forms the body of the boundless universe, together with its members composed of nature's diverse elements, air and fire, earth and level sea, is ruled by the divine force of Soul; by sacred dispensation the god draws things together [conspirat] and governs with hidden reasoning, and he apportions mutual bonds among all parts, so that each may furnish and receive another's strength 
and that the whole may stand fast in kinship despite its variety of forms.-Manilius, Astronomica 1.247-54 (trans. by G. P. Goold, modified) (early first century CE). ${ }^{6}$

T2: It seems to me that the fact that the nature of every animal is adapted (barmoktai) to the cosmos, and to the things in it, is evidenced through many indications. For [each animal's nature], by conspiring (sumpneiousa) with it [sc. the cosmos] and by being bound to a path that is simultaneously best and necessary, follows the stream (rbumai) of the universe that encompasses it, in relation to both the universal good-order (eukosmia) and the peculiar permanence of each [thing?]. Hence, this very thing is called a cosmos, and it is the most perfect of animals that exist. In its parts, which are many and diverse in nature, this animate [sc. cosmos] rules according to its innate properties, and because it has a greater share of what is divine. And, in the nature of the divine continually running (aei theontos theiou), ${ }^{7}$ the things that follow the first and greatest path follow it...[lacuna]...and the wandering planets. - pseudo-Ecphantus of Syracuse, On Kingship, 79.9-14 (mid-first century BCE-mid-first century CE?). ${ }^{8}$

It is important to contextualize these wonderful passages. Manilius' Astronomica, which we can date around $15 \mathrm{CE}$, was written as a cosmic celebration of two Caesars-Augustus Caesar and Tiberius Caesar, the first emperors of Rome. As a whole, the poem is often considered representative of the didactic genre, borrowing much from other didactic poems of the Greek and Roman traditions, including Hesiod's Works and Days, Aratus' Phaenomena, Lucretius' On the Nature of Things, and Virgil's Georgics. It is the earliest surviving explicitly astrological work, and it enjoyed some popularity both in antiquity and in the early twentieth century, having been a particular favourite of A. E. Housman, who devoted thirty years of his life to working on the text.

At punctuated moments, Manilius refers to the organization of the universe-and indeed the organization of the poem itself-as subject to types of primal breathing; this takes the form of, respectively, conspiration and inspiration. To take the latter, a programmatic passage in Book 2 refers to the 'divine exhalation' (divino flatu) that literally inspires his poem to reach the stars themselves (ad sidera). ${ }^{9}$ This is of course a twist on the familiar epic/didactic trope of the poet being inspired by the divine in order to produce a poem that is sufficiently lofty for the genre; but that is not all. As scholars have noted, the poem is infusedno pun intended-with demonstrably Stoic concepts and themes. ${ }^{10}$ The Stoics had developed a sophisticated materialist cosmological system in 
which breath functioned as the primary mechanism for the articulation and sustenance of the parts of the universe. Many passages could be cited and discussed, but Diogenes Laertius presents one of the clearest examples:

T3: The cosmos, they [sc. the Stoics] say, is one and this is limited, having a spherical shape; for a shape of this sort is most suitable for motion, according to Posidonius in the fifth book of his Natural Reason and the followers of Antipater in their works On the Cosmos. Outside this [sc. the cosmos] is diffused the unlimited void, which is incorporeal. By 'incorporeal' they mean that which, although it is capable of being occupied by corporeal things, is not occupied by them. There is no void in the cosmos, but it is wholly unified. For this [sc. unification] necessarily results from conspiration (sumpnoia) and tension (suntonia) of the heavenly things towards the terrestrial things.-Diogenes Laertius, Lives of the Eminent Philosophers, 7.140 (text: early third century CE, looking backwards to the third century BCE). ${ }^{11}$

The entire description is remarkable, ${ }^{12}$ but for the purposes of this essay I want to focus on the last sentence. We can identify here three attributes of the Stoic cosmos: first, the unity of the cosmos, which results from conspiration, is somehow 'necessary'; second, that this conspiration is related to the notion of the 'tension' that obtains between heavenly and terrestrial objects; and third, that the tension and conspiration proceed from heavenly objects down to earthly ones (i.e. are downwardly directed from higher to lower objects ontologically). Given the notion of 'inspiration' by the divine breath we noted previously in Manilius-and which is well attested throughout the poetic tradition from Homer onwards-the downward motion of conspiration and tension is not especially surprising. But we should not take it for granted that Manilius' view that cosmic conspiration is caused by God, or maintained by God, reflects a canonical Stoic view. ${ }^{13}$

Let us now turn from the Stoic notion of cosmic conspiration and focus on how the Post-Hellenistic Pythagoreans developed these ideas. To do this, we can return to the description of cosmogony according to pseudo-Ecphantus of Syracuse in On Kingship. The text of pseudoEcphantus belongs to a series of Pythagorean pseudepigrapha-texts that were ascribed to the ancient Pythagoreans (who lived at the beginning of the fifth century BCE but probably wrote little if anything), but that were composed starting from, at the earliest, around 350 years later, in the 
mid/late second century BCE. ${ }^{14}$ This particular text appears to have been composed around the turn of the millennium, although we cannot be sure exactly when. ${ }^{15}$ Pseudo-Ecphantus hints at the notion of cosmic harmony in the first line, where the Greek term harmoktai, which means 'adjusted to' or 'fitted to', refers to the Pythagorean concept of the 'harmony (barmonia) of the spheres'-well attested both in early Pythagorean philosophy, and in the pseudepigraphical works of this period. PseudoEcphantus aims to demonstrate, by appeal to evidence (the 'indications'), that each 'animal' is properly fitted to, or harmonized with, the cosmos as a whole. These 'animals' could include not only mundane objects, like human beings or dogs, but also, and more importantly, stars and planets, which, by virtue of being capable of moving themselves, were considered animate by the Pythagoreans of this period. ${ }^{16}$ But they are all subject to the greatest and most perfect animal of all-the cosmos, which rules over everything inside it. Of special importance to our subject is the idea that each animate being that is ruled over by the cosmos 'conspires' with it, and this act of conspiration is emblematic of each animal's engagement with the 'stream' or flux of the universe. In another fragment of this work, we find that all humans have a divinely portioned inspiration (empnoiesis), and, at least among terrestrial creatures, they appear to share to the greatest extent in the divine breath. ${ }^{17}$

That the ascription of a theory of cosmic conspiration is being associated with a great Pythagorean cosmologist is itself unsurprising, since the Pythagoreans were among the very first Greek philosophers to conceptualize the articulation of the cosmos as an act of breathing. ${ }^{18}$ However, what differentiates pseudo-Ecphantus' On Kingship from what we can trace back to early Pythagoreanism 350 years prior, is that here each ensouled animal itself breathes in unison, or 'co-breathes', along with the cosmos, whereas among the early Pythagoreans it was the cosmos as a whole that did the breathing and not its parts (at least so far as the surviving evidence suggests). ${ }^{19}$ That is to say, for pseudo-Ecphantus, in the act of conspiring with the universe, each animal plays its own part in the cosmic system and carves its own path in accordance with its peculiar capacities. Such an act of 'conspiration' might seem to indicate agency on the part of the lower animate beings. But how much agency do these Post-Hellenistic Pythagoreans really accord to lower animate beings vis-àvis conspiration? Other roughly contemporary evidence shows that some figures, like Moderatus of Gades (a self-proclaimed Pythagorean ${ }^{20}$ who probably lived at the end of the first century $\mathrm{CE}$ ), understood the one $e^{21}$ to be the ultimate cause of such a cosmic conspiration from, just as we 
saw for the Stoics, the top down. Moderatus believed that the number one is the 'cause of the conspiration and the sympathy of wholes':

T4: Geometricians too, since they do not have the ability to express incorporeal things in speech, have recourse to figural diagrams when they say 'this is a triangle': they do not mean that what falls to the eye is the triangle, but that it [sc. the triangle] is of this sort, and it is through this that they express the concept of the triangle. And the Pythagoreans did the same thing in the case of primary reasons and types: since they did not have the ability to express the incorporeal types and first principles in speech, they had recourse to numerical demonstration. And in this way they called the one the reason of unity, and of identity and equality; and they called it the cause of the conspiration (sumpnoia) and the sympathy (sumpatheia) of wholes, and of the preservation of what is absolute and as such: for, indeed, when it is among things [divided] part by part, the one subsists by unifying with the parts, and by conspiring (sumpnoun) with them according to participation in the primary cause. ${ }^{22}$ - Porphyry of Tyre, citing Moderatus of Gades, Life of Pythagoras 49 (text: late third century CE, looking back at end of first century CE). ${ }^{23}$

Here we see a remarkable account of how cosmic conspiration works. Moderatus explains that the early Pythagoreans needed to be able to explain how incorporeal things, such as the ultimate causes of everything in the universe or the ultimate species of existence, could be formulated in speech, when they could not be seen by the eye. They appealed to numbers, which belong to both the world of the concept and the world of sense-perception: for example, we can see the twoness of two pints of beer with our eyes, but at the same time we can think 'twoness' in our heads without having to associate it with the two pints of beer we are seeing. For these Pythagoreans, numbers were substantial rather than (as Aristotle might hold) quantitative predicates, which indicated something fundamental about the identity of the object under examination. The number one, which is solicited here, for example, is understood to be the explanation for unity, equality, and identity of enumerated objects. It is equally understood to be the cause of 'conspiration and sympathy' among those objects, that which allows them to participate in the ultimate cause of all, namely, the One (not the number one, but the One that is above all Being and Existence). ${ }^{24}$ As with the Stoics, conspiration is understood to be a top-down mechanism that explains the unity 
of the diversity of the cosmos; higher beings-whether we call them 'God', or 'the divine', or 'the number one', or 'the One'-are responsible for sustaining the act of cosmic breathing, and lower animate beings simply reciprocate the action by necessity. Among the Stoics and the Hellenistic/Post-Hellenistic Pythagoreans, then, conspiration is similarly asymmetrical and top down.

In the final part of this essay, I want to turn to the origins of the notion of cosmic conspiration. If the concept was not really developed by the Early Pythagoreans, where, and when, we might ask, did it ultimately arise? The ostensible answer reveals as many questions about the problem as it does solutions. It comes in the writings of the famous physician Galen (ca. $130 \mathrm{CE}-$ ca. $210 \mathrm{CE})$ :

T5: If, on the other hand, we were to bring forward philosophers from the Stoa to the council chamber and entrust the vote to them, on the basis of the doctrines they themselves have put forward, they will crown Hippocrates. For Hippocrates was the first to propose [the elemental qualities of] hot, cold, dry and moist and, after him, Aristotle proved them.

And the followers of Chrysippus, when they accepted these things already to hand, were not embroiled in contention. Rather, they say that all things are compounded from these [four elemental qualities], and that these things are affected by and act on each other, and that nature is proficient. And they approve all the other doctrines of Hippocrates regarding nature, apart from one minor point which is a difference between them and Aristotle. For when Hippocrates correctly says that 'the whole body conspires (sumpnoun) and flows together (surroun)', and that 'all the members of animate things are [in] sympathy (sumpathea)', both accept this very point. However, they differ in this: Aristotle held that the qualities alone interpenetrate each other and are mixed together completely, whereas those from the Stoa suppose that not these qualities only but also the substances themselves [are mixed completely].-Galen, Method of Medicine 1.2, ${ }^{25}$ attacking Thessalus and defending Hippocrates (trans. by Ian Johnston and G. H. R. Horsley, modified) (text: mid-second century CE).

Thankfully, we actually have the passage Galen is summarizing, from the treatise On Nutriment, ascribed to Hippocrates of Chios (ca. 460-ca. $375 \mathrm{BCE}$ ), who was a rough contemporary of the early Pythagoreans: 
T6: XXIII. Conflux (surroia) one, conspiration (sumpnoia) one, [in] sympathy (sumpathea) all things; in wholeness of limbs, all things, but severally, the parts in each part relative to the function.

XXIV. The great beginning comes to the furthest part; from the furthest part it travels to the great beginning: one nature, to be and not to be. -Pseudo-Hippocrates, On Nutriment 23-24, p. 143.1 Joly, 9.106,6 (before mid-second century CE). ${ }^{26}$

Now when we examine these texts, we face a similar problem to that faced with the text of pseudo-Ecphantus. It is not certain that On Nutriment reflects Hippocrates' own words: rather we are dealing here with a textual tradition in which Hippocratic texts were produced over a long period of time. Scholars have attempted to date this text to a period as early as the beginning of the fourth century $\mathrm{BCE} ;{ }^{27}$ at any rate, we need to date it prior to Galen, who knew it in the mid-second century CE. Does the style help us to adjudicate the matter? Someone might describe it as archaic, or as archaizing: as Craik notes, the style is aphoristic, ${ }^{28}$ and we might think it could reflect anything from Heraclitean riddle to a Hippocratic physician's crib notes. But here Galen is instructive: he places the document within a 'first discoverers' topos, using (his own interpretation of) the Hippocratic text to demonstrate that Hippocrates was the first to advance a theory of the elemental qualities. He is at pains to demonstrate that Hippocrates anticipated the elemental theories of the Stoics (especially Chrysippus) and Aristotle, and that they agreed with him in most ways. This is a worrying sign, because it is not obvious that Aristotle agreed with Hippocrates at all on this point; and while the Stoics would appear to have agreed with him (as well as the Post-Hellenistic Pythagorean pseudo-Ecphantus, and the Neo-Pythagorean Moderatus), this would point to a Stoic origin for the aphoristic statement 'Conflux one, conspiration one, [in] sympathy all things'; after all, the evidence for Stoic conspiration as sympathy is robust, whereas this is the only evidence for a similar idea among Hippocratics. It seems likely, then, that the Hippocratic On Nutriment is a text influenced by Stoicism, rather than the other way around, and moreover that similarities in the formulation found among the Post-Hellenistic Pythagoreans also point to a Stoic origin.

What are we left with at the end of this selective discussion of notions of cosmic conspiration? After examining texts written by a Roman didactic poet (Manilius), some Post-Hellenistic Pythagoreans (pseudo-Ecphantus 
and Moderatus), a materialist philosophical school (the Stoics), a famous doctor (Galen), and an unknown author of an enigmatic medical text (the Hippocratic author of On Nutriment), we can conclude that cosmic conspiration as described here is ultimately the brainchild of the Stoics, and probably the transformative Chrysippus of Soli, whose contributions to philosophy are so wide and varied it becomes almost impossible to determine them. In this way he resembles the legendary Pythagoras and Hippocrates - with the exception that it is less common to see ancient philosophers and doxographers crediting Chrysippus with major contributions to the history of thought.

By way of a coda, to give some indication of where things go from Galen, it is worth considering a text written by Clement (ca. $150 \mathrm{CE}-$ ca. $215 \mathrm{CE}$ ), a Christian theologian and convert who lived and taught in Alexandria, a centre for philosophical activity and culture since the time of Aristotle. As teacher of the immensely influential Origen of Alexandria, Clement is to be counted as especially important in the transformation of Greek philosophy to Christian doctrine. In the following passage of his Miscellanies Clement both appropriates and rejects the philosophical and medical models of 'conspiration', in favour of something apparently different:

T7: What, then, is their [sc. the worshippers'] idea as to the breathing of God? Is it by means of transpiration as in the demons? Or by inspiration only, as in fishes through the dilation of their gills? Or by circumspiration, as in insects through the pressure of the membranes on the waist? No, they would not liken God to any of these, if they were in their senses. But as for creatures that live by respiration, they draw in the air by rhythmic beats corresponding to the counter-dilatation of the lungs against the chest. Then if they assign viscera and arteries and veins and sinews and members to God, they will exhibit Him as in no respect differing from man.

The word 'conspiration' (sumpnoia) is that which is properly used of the Church. For the Church's sacrifice is indeed speech rising, like incense, from holy souls, while every thought of the heart is laid open to God along with the sacrifice. They are fond of talking about the purity of the most ancient altar at Delos, that altar which, we are told, was the only one approached by Pythagoras, because it was unpolluted by slaughter and death: will they then refuse credence to us when we say that the truly hallowed altar is the righteous soul, and the incense which ascends from it, the prayer of holiness? Sacrifices, I believe, are an invention of mankind to excuse the eating of flesh, though, even apart 
from such idolatry, it was always possible for one who wished it to partake of flesh.-Clement of Alexandria, Miscellanies VII 6.32 (trans. by Hort and Mayor) (late second century CE). ${ }^{29}$

It may be that Clement found in his doxographical sources the rather typical claim that ascribed a high value to the notion of breath and breathing to Pythagoras; and, indeed, this association is as old as Aristotle in the mid-fourth century BCE. ${ }^{30}$ Clement's rejection of anthropomorphizing God rests on the implication that He cannot 'breathe' in any way similar to the animals $\mathrm{He}$ created; and it is a point well taken, if not very original. ${ }^{31}$ However, this rejection also places certain special demands on Christian readers of, for example, Genesis 2:7, where famously God breathes into the nostrils of Adam in order to give him life: how are we to explain this obvious analogy drawn between God and Man, both of whom breathe? ${ }^{32}$ Clement's solution to the problem, to find in the Church the proper space for deployment of the powerful metaphor of conspiration, is inflected with Pythagorean and Stoic ideas that trace back, at the very latest (and possibly earlier), to the first century BCE, whereby conspiration is a collaborative effort that somehow connects mere mortals to the highest reaches of the cosmos-even to God. In this way, Clement offers a resonant example of how the Christian writers of the second and third centuries $\mathrm{CE}$ sought to reject pagan philosophical doctrines as absurd and contrary to Christian wisdom, while still carefully manipulating and repurposing their content in almost imperceptible ways.

\section{Notes}

1. Also see Phillip Sidney Horky, 'Cosmic Spiritualism among the Pythagoreans, Stoics, Jews, and Early Christians', in Cosmos in the Ancient World, ed. by Phillip Sidney Horky (Cambridge: Cambridge University Press, 2019), 270-94. For a fuller account of ancient cosmic breathing, readers are encouraged to consult that piece, which was also produced from work undertaken for the Life of Breath project. For a more scientific approach to the history of breath and its meaning in Greco-Roman culture, see Long's contribution in Chapter 2 of this volume. Unless otherwise noted, translations of Greek and Latin texts are my own.

2. The earliest evidence of this usage is mid-first century BCE: Caesar, Commentarii. I. Bellum Gallicum, ed. by R. L. A. Du Pontet (Oxford: Oxford University Press, 1963), 3.10.3; T. Livius, Ab Urbe Condita, vol. 
1, bks 1-5, ed. by R. M. Ogilvie (Oxford: Oxford University Press, 1974), 3.64.1. etc.

3. The earliest reference of this usage in Latin occurs around 140 BCE: Accius, in Remains of Old Latin, Volume II: Livius Andronicus. Naevius. Pacuvius. Accius., ed. by E. H. Warmington (Cambridge, MA: Harvard University Press, 1936), Frs. 648-49: 'O suavem linguae sonitum! o dulcitas conspirantum animae!' ( $\mathrm{O}$ pleasant sound of the tongue! $\mathrm{O}$ sweetness of the soul of those who breathe as one!).

4. Epicurean: T. Lucretius, De Rerum Natura: Libri Sex, 2nd edn, ed. by C. Bailey (Oxford: Oxford University Press, 1923), 4.1212-17; Stoic: G. Musonius Rufus, Reliquiae, ed. by O. Hense (Leipzig, Teubner, 1905), $13 a$.

5. At Plutarch, Life of Aratus 24.5, in Plutarch, Plutarch's Lives, trans. by B. Perrin (Cambridge, MA: Harvard University Press, 1926), Aratus considers how the weak Greek poleis could be preserved by mutual support through a common agreement, and that 'just as the members of the body have a common life and breath because they cleave together in a common growth, but when they are drawn apart and become separate they wither away and decay, in a like manner the several states are ruined by those who dissever their common bonds, but are augmented by mutual support, when they become parts of a great whole and enjoy a common foresight' (trans. by Perrin).

6. Manilius, Astronomica, ed. and trans. by G. P. Goold (Cambridge, MA: Harvard University Press, 1977).

7. This is an apparent etymologization of 'aether' as 'always running' (aei theontos). The 'upper' aether constituted the region associated with the sphere of the sun, stars, and planets in Hellenistic/PostHellenistic Pythagoreanism. See, e.g., Alexander Polyhistor at Diogenes Laertius, Lives of the Eminent Philosophers, ed. by T. Dorandi (Cambridge: Cambridge University Press, 2013), 8.26-27.

8. The edition of the Pythagorean Pseudepigrapha and related testimonies used throughout is Holger Thesleff, The Pythagorean Texts of the Hellenistic Period (Åbo: Åbo Akademi, 1965).

9. Manilius, Astronomica, 2.136-37.

10. See Katharina Volk, Poetics of Latin Didactic: Lucretius, Vergil, Ovid, Manilius (Oxford: Oxford University Press, 2002), ch. 6.

11. Cf. Hans von Arnim, ed., Stoicorum Veterum Fragmenta, 3 vols (Berlin: de Gruyter, 1978), 3.43 (Antipater) (part) and 2.543 (part).

12. See, e.g., Horky, 'Cosmic Spiritualism', 275-77.

13. There is even some room for debate on this point among the Stoics, if we are to believe pseudo-Plutarch's account of Stoic cosmology: 'this cosmos, being conspirative (sumponoun) and co-affected (sumpathe) itself 
with itself, is governed by nature' (von Arnim, ed., Stoicorum Veterum Fragmenta, 2.192).

14. For general accounts, see Giulia De Cesaris and Phillip Sidney Horky, 'Hellenistic Pythagorean Epistemology', Lexicon Philosophicum Special Issue: Hellenistic Theories of Knowledge (2018), 221-23; and Bruno Centrone, 'The pseudo-Pythagorean Writings', in A History of Pythagoreanism, ed. by Carl A. Huffman (Cambridge: Cambridge University Press, 2014), 321-26.

15. For a review of the various positions advanced, see Francesca Calabi, God's Acting, Man's Acting: Tradition and Philosophy in Philo of Alexandria (Leiden: Brill, 2007), 186-88.

16. The origins of this notion are to be found ultimately in the activity of the World-Soul, identified as a living being in Plato, Timaeus 30b6-cl, in Plato, Opera, Volume IV: Clitopho, Respublica, Timaeus, Critias, ed. by J. Burnet (Oxford: Oxford University Press, 1922).

17. Cf. pseudo-Ecphantus, On Kingship, Thesleff, Pythagorean Texts, 79.2-714. On this passage and its relations to Philo, see Calabi, God's Acting, 200-03. It is surprising that Calabi does not note that all other animate beings also 'conspire' with the cosmos in particular. Hence, her interpretation of the passage, which claims that 'it seems ... far more likely that the breath [of man] derives from god', does not address the point that it is the cosmos that engages in conspiration, and not god (as in Philo, who is influenced by Genesis).

18. See Horky, 'Cosmic Spiritualism', 272-75.

19. Ibid.

20. He is often referred to as a 'Neo-Pythagorean' (cf. John Dillon, The Middle Platonists: 80 B.C. to A.D. 220, rev. edn (London: Duckworth, 1996), 341).

21. Typically, we would be inclined to capitalize as 'the One'; but it is clear, as we see in the passage, that Moderatus does not mean to refer to the divine One, or the god One, to which the Middle Platonists deferred.

22. That this passage ultimately derives from Moderatus is clear from Porphyry, Life of Pythagoras 48, where Porphyry tells us that Moderatus treated Pythagorean numerology and compared their approach to that of the geometricians.

23. Porphyre, Vie de Pythagore, Lettre à Marcella, ed. by Edouard des Places (Paris: Les Belles Lettres, 1982).

24. On the three Ones in Moderatus' ontology, see Dillon, Middle Platonists, 347, and the cautionary remarks of Svetla Slaveva-Griffin, Plotinus on Number (Oxford: Oxford University Press, 2009), 44-46.

25. Galen, Method of Medicine, vol. 1, bks 1-4, ed. and trans. by I. Johnston and G. H. R. Horsley (Cambridge, MA: Harvard University Press, 2011), 1.27-28. Cf. von Arnim, ed., Stoicorum Veterum Fragmenta, 2.411. 
26. Hippocrate, $D u$ régime des maladies aiguës, De l'aliment, De l'usage des liquides, vol. 6.2, ed. by R. Joly (Paris: Les Belles Lettres, 1972), 9.106,6.

27. E.g., Elizabeth M. Craik, The 'Hippocratic' Corpus: Content and Context (London: Routledge, 2015), 26 (who follows Joly).

28. Ibid.

29. Fenton John Anthony Hort, and Joseph B. Mayor, Clement of Alexandria: Miscellanies Book VII (London: Macmillan, 1902), 5.5.

30. See Horky, 'Cosmic Spiritualism', 272-75.

31. The rejection of anthropomorphic gods is as old as Xenophanes of Colophon in the late-sixth-century BCE (see Hermann Diels and Walther Kranz, Die Fragmente der Vorsokratiker, 6th edn, vol. 2 (Berlin: Weidmann, 1952), 21 B 11-12, 14, and 23).

32. The Hellenic Jew Philo of Alexandria ( $c a$. first century CE) attempts to explain it in different ways. See Horky, 'Cosmic Spiritualism', 281-86.

\section{BIBLIOGRAPHY}

Calabi, Francesca. 2007. God's Acting, Man's Acting: Tradition and Philosophy in Philo of Alexandria. Leiden: Brill.

Centrone, Bruno. 2014. "The Pseudo-Pythagorean Writings." In A History of Pythagoreanism, ed. Carl A. Huffman, 315-34. Cambridge: Cambridge University Press.

Craik, Elizabeth M. 2015. The "Hippocratic" Corpus: Content and Context. London: Routledge.

De Cesaris, Giulia, and Phillip Sidney Horky. 2018. "Hellenistic Pythagorean Epistemology." Lexicon Philosophicum. Special Issue: Hellenistic Theories of Knowledge: 221-62.

Dillon, John. 1996. The Middle Platonists: 80 B.C. to A.D. 220, Rev. edn. London: Duckworth.

Horky, Phillip Sidney. 2019. "Cosmic Spiritualism among the Pythagoreans, Stoics, Jews, and Early Christians." In Cosmos in the Ancient World, ed. Phillip Sidney Horky, 270-94. Cambridge: Cambridge University Press.

Hort, Fenton John Anthony, and Joseph B. Mayor, eds 1902. Clement of Alexandria: Miscellanies Book VII. London: Macmillan.

Slaveva-Griffin, Svetla. 2009. Plotinus on Number. Oxford: Oxford University Press.

Thesleff, Holger. 1965. The Pythagorean Texts of the Hellenistic Period. Åbo: Åbo Akademi.

Volk, Katharina. 2002. Poetics of Latin Didactic: Lucretius, Vergil, Ovid, Manilius. Oxford: Oxford University Press. 
Open Access This chapter is licensed under the terms of the Creative Commons Attribution 4.0 International License (http://creativecommons.org/licenses/ by $/ 4.0 /$ ), which permits use, sharing, adaptation, distribution and reproduction in any medium or format, as long as you give appropriate credit to the original author(s) and the source, provide a link to the Creative Commons license and indicate if changes were made.

The images or other third party material in this chapter are included in the chapter's Creative Commons license, unless indicated otherwise in a credit line to the material. If material is not included in the chapter's Creative Commons license and your intended use is not permitted by statutory regulation or exceeds the permitted use, you will need to obtain permission directly from the copyright holder.

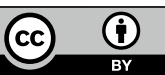

